\title{
WERYFIKACJA I WALIDACJA NOWEGO ALGORYTMU PLANOWANIA TRAS W PRZESTRZENI FRA
}

\author{
ANDRZEJ MAJKA \\ Politechnika Rzeszowska, Katedra Inżynierii Lotniczej i Kosmicznej, Rzeszów \\ e-mail: andrzej.majka@prz.edu.pl
}

\begin{abstract}
Europa stoi przed kryzysem przepustowości przestrzeni powietrznej, ponieważ prognozuje się, że liczba lotów wzrośnie nawet o 50\% w ciągu najbliższych 10-20 lat. Niska efektywność spowodowana rozdrobnieniem europejskiej przestrzeni powietrznej wywołuje co roku wysokie dodatkowe koszty, które ponoszone są głównie przez przewoźników i pasażerów. Obwiązujące zasady planowania lotów sprawiają, że plany lotu rzadko są zgodne z ich operacyjną realizacją. Efektem tego jest niska przewidywalność ruchu lotniczego wpływająca na duże obciążenie kontrolerów ruchu lotniczego w trakcie rozwiązywania sytuacji konfliktowych oraz na duże opóźnienia w ruchu lotniczym. Brak możliwości skutecznej optymalizacji trasy na etapie planowania lotu sprawia, że europejskie trasy lotu są wydłużone w stosunku do rozwiązań optymalnych, co w konsekwencji oznacza większe zużycie paliwa, wzrost emisji zanieczyszczeń oraz wyższe koszty dla użytkowników. Praca dotyczy sprawdzenia poprawności działania nowego algorytmu planowania tras w przestrzeni FRA, opisanego w [7], pozwalającego na uwzględnienie złożoności przestrzeni powietrznej oraz ograniczeń w niej występujących. Opracowany algorytm może być wykorzystywany w zautomatyzowanych systemach planowania lotu, dostępnych dla niekomercyjnych użytkowników (General Aviation) lub mniejszych firm lotniczych (Business Aviation, Remotely Piloted Aircraft Systems). Weryfikacja otrzymanych wyników przeprowadzona została przez porównanie otrzymanych tras z trasami zaplanowanymi ręcznie przez pilotów zawodowych o dużym doświadczeniu lotniczym. Walidacja, wykazująca wykonalność zaplanowanych tras, przeprowadzona została z wykorzystanie symulatora lotu klasy FNPT II w trakcie symulowanych lotów w czasie rzeczywistym.
\end{abstract}

\section{Wstęp}

Najgęstszy ruch lotniczy występuje w Europie i w północno-wschodnim korytarzu USA. Obserwacje w tych obszarach wskazują, że ruch lotniczy zbliżający się do granicy przepustowości sektorów przestrzeni powietrznej wywołuje wiele niepożądanych konsekwencji:

(i) opóźnienia odlotów i przylotów, wywołujące rosnące niezadowolenie pasażerów oraz możliwie straty w działalności biznesowej,

(ii) tworzenie się długich kolejek samolotów, zarówno na ziemi jak i w powietrzu,

(iii) zwiększenie zużycia paliwa i wzrost emisji hałasu oraz substancji szkodliwych do środowiska w obszarach wokółlotniskowych, które są wyjątkowo wrażliwe na tego typu oddziaływania,

(iv) efekty powiązane z poprzednimi, dotyczące strat ekonomicznych wynikających nie tylko ze zwiększonego zużycia paliwa i zwiększonej emisji, ale również utraty czasu operacyjnego samolotów oraz pasażerów odbywających loty służbowe.

Dzięki postępowi technologicznemu i nowym rozwiązaniom proceduralnym w obszarze zarządzania ruchem lotniczym (ATM), zarówno w Europie jak i USA, udaje się w większości przypadków zaradzić niepożądanym konsekwencjom wynikającym z rosnącego ruchu lotniczego. Margines bezpieczeństwa nie jest jednak zbyt duży, o czym świadczą pojawiające się opóźnienia 
oraz nieregularności ruchu. Ogólne wyzwanie polegające na kompleksowej poprawie sytuacji ciągle jest więc aktualne i jest rozpoznawane zarówno na szczeblu politycznym, jak i operacyjnym. Świadczą o tym duże programy naprawcze, takie jak SESAR w Europie i NextGen w USA, których zadaniem jest opracowanie nowych rozwiązań oraz dostarczenie dowodów na to, że proponowane rozwiązania techniczne i organizacyjne wyprzedzają potrzeby wynikające z rosnącego ruchu lotniczego. Sytuacja w Europie i w USA jest jednak odmienna i wymaga nieco innego podejścia do poszukiwania efektywnych rozwiązań, choć proponowane rozwiązania muszac być spójne, ze względu na globalny charakter transportu lotniczego oraz konieczność „zszywania” się systemów na ich styku.

Historycznie Europa składała się z szeregu państw, które nie tworzyły jednolitych systemów politycznych, gospodarczych ani demograficznych. Miało to również wpływ na inną organizację ruchu lotniczego i przestrzeni powietrznej w każdym kraju. Zacieśnianie współpracy gospodarczej doprowadziło do powstania szeregu form kooperacji, integrujących kraje Europy politycznie, gospodarczo oraz społecznie. Miało to również odzwierciedlenie w staraniach do ujednolicenia zasad ruchu lotniczego i zarządzania przestrzenią powietrzną dla całej Unii Europejskiej. Proces tworzenia jednolitej przestrzeni powietrznej (Single European Sky - SES) zainicjowany został przez Komisję Europejską w 2000 r. szeregiem działań legislacyjnych. Mimo podejmowanych działań w Europie system zarządzania ruchem lotniczym (ang. ATM - Air Traffic Management) jest cząstkowy, rozdrobniony i zdominowany przez krajowe podmioty posiadające monopol na świadczenie usług w zakresie ATM. Niska wydajności systemu wynika z funkcjonalnego podziału przestrzeni powietrznej według granic państwowych, który w pewnym zakresie nadal obowiązuje. Nieodpowiednia organizacja oraz brak pełniej integracji systemu ATM skutkował między innymi:

- mało efektywną strukturac europejskiej sieci dróg lotniczych, a w konsekwencji niepotrzebnym wydłużeniem tras i czasu lotu, dodatkowym zużyciem paliwa, zwiększoną emisją spalin, zawyżonymi kosztami itd.,

- opóźnieniami w ruchu lotniczym,

- zaniżonym poziomem wydajności ruchu lotniczego,

- zróżnicowanymi wymaganiami w zakresie bezpieczeństwa, ekonomiki i przepustowości wynikającymi z możliwości krajowych Dostawców Usług Nawigacji Lotniczej (ang. ANSP Air Navigation Service Provider),

- wysokimi kosztami spowodowanymi eksploatacją nadmiernej liczby przestarzałych urządzeń i systemów nawigacyjnych i innych elementów infrastruktury (ang. CNS - Communication, Navigation and Surveillance, ATM - Air Traffic Management),

- opóźnieniami w zakresie wdrażania nowych technologii.

Europa dodatkowo stoi przed kryzysem przepustowości przestrzeni powietrznej, ponieważ prognozuje się, że liczba lotów wzrośnie nawet o $80 \%$ w ciągu najbliższych 20 lat (rys. 1) [2]. Niska efektywność spowodowana rozdrobnieniem europejskiej przestrzeni powietrznej wywołuje co roku dodatkowe koszty w wysokości ok. 5 mld euro, które są ponoszone głównie przez przewoźników i pasażerów. Obwiązujące zasady planowania lotów sprawiają, że plany lotu rzadko są zgodne z ich operacyjną realizacją. Efektem tego jest niska przewidywalność ruchu lotniczego wpływająca na duże obciążenie kontrolerów ruchu lotniczego w trakcie rozwiązywania sytuacji konfliktowych oraz na duże opóźnienia w ruchu lotniczym. Brak możliwości skutecznej optymalizacji trasy na etapie planowania lotu sprawia, że europejskie trasy lotu są wydłużone średnio o $42 \mathrm{~km}$ w stosunku do rozwiązań optymalnych, co w konsekwencji oznacza większe zużycie paliwa, wzrost emisji zanieczyszczeń, wyższe koszty dla użytkowników [7], [16].

Odpowiedzią na te problemy było zainicjowanie programu SESAR (Single European Sky ATM Research) stanowiącego technologiczny filar SES [16]. Celem tego programu jest opracowanie i wdrożenie nowoczesnego systemu ATM pozwalającego zwiększyć przepustowość sieci ATM, aby sprostać stale rosnącej ilości operacji lotniczych przy jednoczesnej poprawie wskaźni- 


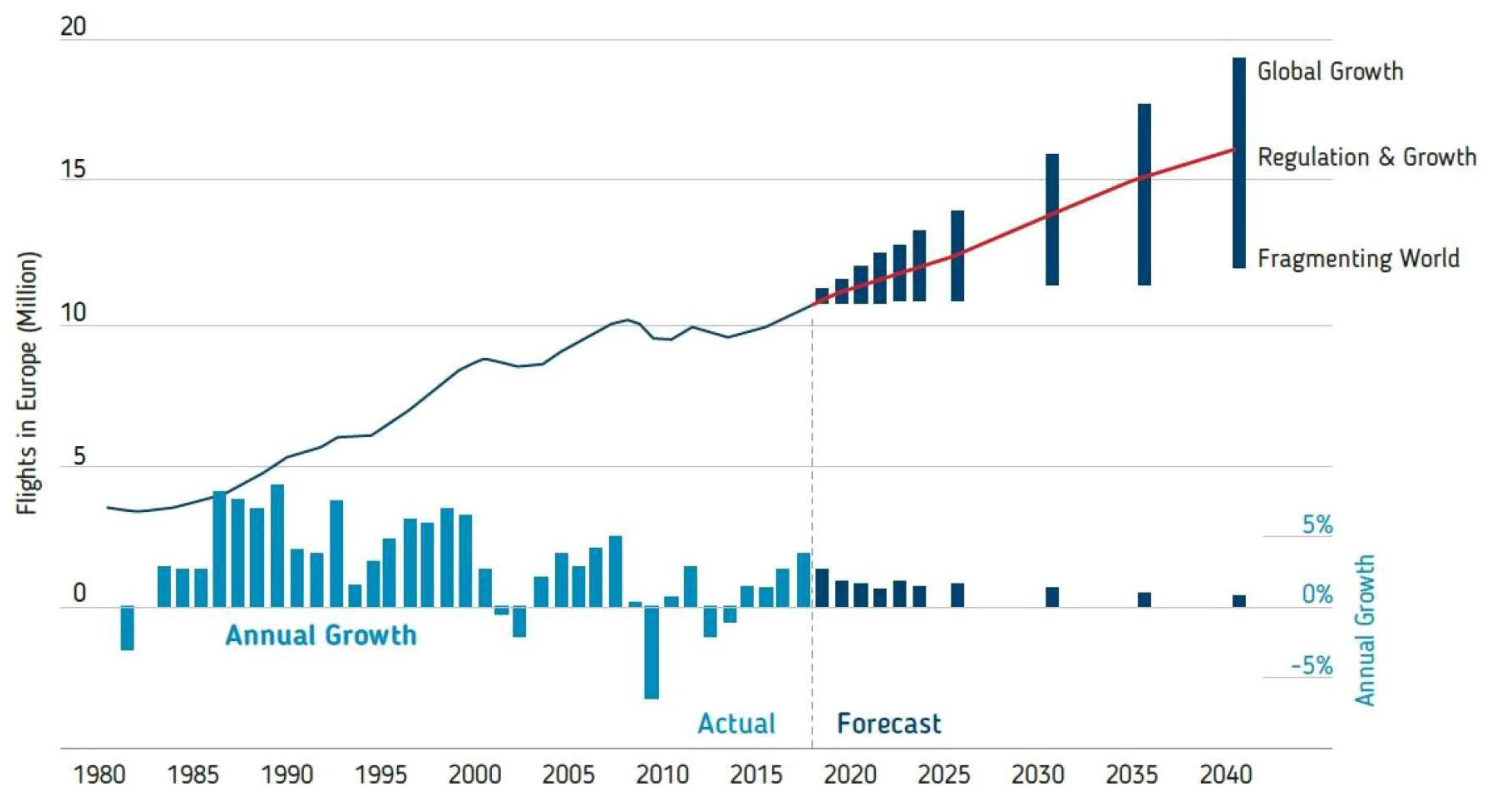

Rys. 1. Prognoza długoterminowa wzrostu ruchu lotniczego na terenie UE [2]

ków ekonomicznych i bezpieczeństwa. Zastosowanie nowoczesnych technologii i procedur pozwoli również na zredukowanie negatywnego wpływu transportu lotniczego na środowisko naturalne. Skuteczna realizacja programu SESAR w znacznym stopniu przyczyni się do osiągnięcia strategicznych celów SES [16]:

- trzykrotnego zwiększenia przepustowości,

- poprawy wskaźników bezpieczeństwa,

- $10 \%$ redukcji negatywnego wpływu lotnictwa na środowisko naturalne,

- $50 \%$ redukcji kosztów ATM (do poziomu porównywalnego z kosztami w USA).

\section{Free Route Airspace (FRA)}

Europejska cywilna przestrzeń powietrzna dzieli się na przestrzeń kontrolowaną i niekontrolowaną. W przestrzeni powietrznej kontrolowanej za utrzymanie bezpiecznych separacji pomiędzy samolotami odpowiedzialny jest kontroler. W przestrzeni niekontrolowanej cała odpowiedzialność spoczywa na pilocie. Praktycznie cały ruch pasażerski odbywa się przestrzeni powietrznej kontrolowanej.

Europejska przestrzeń powietrzna kontrolowana jest jedną z najbardziej „regulowanych” przestrzeni powietrznych na świecie. To w naturalny sposób prowadzi do nieefektywności, które prawdopodobnie zostaną rozwiązane za pomocą większej liczby regulacji. Ponieważ Europa postawiła sobie za cel poprawę efektywności lotów, to zaczęto poszukiwać rozwiązań, które to umożliwią. W 2008 r. pojawiła się nowa koncepcja planowania lotów, dająca większą swobodę planowania tras przelotu przez daną przestrzeń powietrzną bezpośrednio pomiędzy zdefiniowanymi punktami nawigacyjnymi, początkowym i końcowym lub wlotowym i wylotowym. Proponowany sposób planowania lotu nie wymaga wykorzystywania istniejącej sieci dróg lotniczych, umożliwia za to korzystanie z dodatkowych punktów nawigacyjnych zdefiniowanych przez użytkownika. Nowy sposób planowania lotu został nazwany Free Route Planning, a przestrzeń, w której jest on możliwy do zastosowania, została nazwana Free Route Airspace (FRA). Przestrzeń powietrzna typu FRA jest postrzegana jako rozwiązanie, które może uwolnić potencjał swobodniejszego sposobu kierowania ruchem lotniczym w całej Europie. Głównym celem wprowadzenia nowego sposobu planowania lotów było umożliwienie wyboru najbardziej wydajnych 
tras i wysokości lotu, w efekcie uzyskując zmniejszenie zużycia paliwa oraz emisji dwutlenku węgla, a także minimalizację opóźnień spowodowanych ograniczoną dostępnością tras przy rosnącym obciążeniu ruchem lotniczym w przyszłości.

W 2013 r. 13 spośród 64 europejskich ośrodków kontroli obszaru ACC (ang. Area Control Centre) znajdowało się na rożnych poziomach wprowadzania koncepcji FRA. Stanowiło to ponad $25 \%$ powierzchni objętej zarządzaniem i usługami EUROCONTROL [3]. Wprowadzenie FRA ma docelowo doprowadzić do dziennego skrócenia tras pokonywanych przez samoloty na terenie Europy o około $25000 \mathrm{NM}$ (mil morskich) i odległości pokonywanych przez samoloty w skali roku o około $7,5 \mathrm{mln} \mathrm{NM}$, co przełoży się na zmniejszenie zużycia paliwa o ok. 45000 ton i redukcję emisji substancji szkodliwych na poziomie 150000 ton. Obciążenia ekonomiczne użytkowników przestrzeni powietrznej powinny zmniejszyć się o ok. $37 \mathrm{mln}$ euro rocznie [3].

W biuletynie AIC 03/18 Polskiej Agencji Żeglugi Powietrznej poinformowano o wprowadzeniu w FIR Warszawa przestrzeni FRA o nazwie POLFRA [15]. Jest to kolejny krok do optymalizacji operacji lotniczych w FIR Warszawa w celu zapewnienia korzyści operacyjnych, środowiskowych i kosztowych, przy jednoczesnym utrzymaniu obecnego poziomu bezpieczeństwa i przepustowości. Przestrzeń FRA w FIR Warszawa (POLFRA) rozciąga się od poziomu FL095 do FL660, z wyłączeniem przestrzeni TMA/MTMA oraz CTR/MCTR i jest dostępna 24 godziny na dobę. Wdrożenie POLFRA przypadło na dzień 28 lutego 2019 r.

Początkowo planowanie tras w przestrzeni POLFRA, podobnie jak w większości obszarów FRA w Europie, będzie możliwe tylko w oparciu o tzw. predefiniowane punkty nawigacyjne (ang. pre-defined way points), bez możliwości definiowania nowych, tzw. user-defined way points. W przypadku przestrzeni POLFRA będzie więc do dyspozycji ok. 635 znaczących punktów nawigacyjnych (rys. 2), na podstawie których będą wyznaczane trasy zgodnie z zasadami FRA $[14]$.

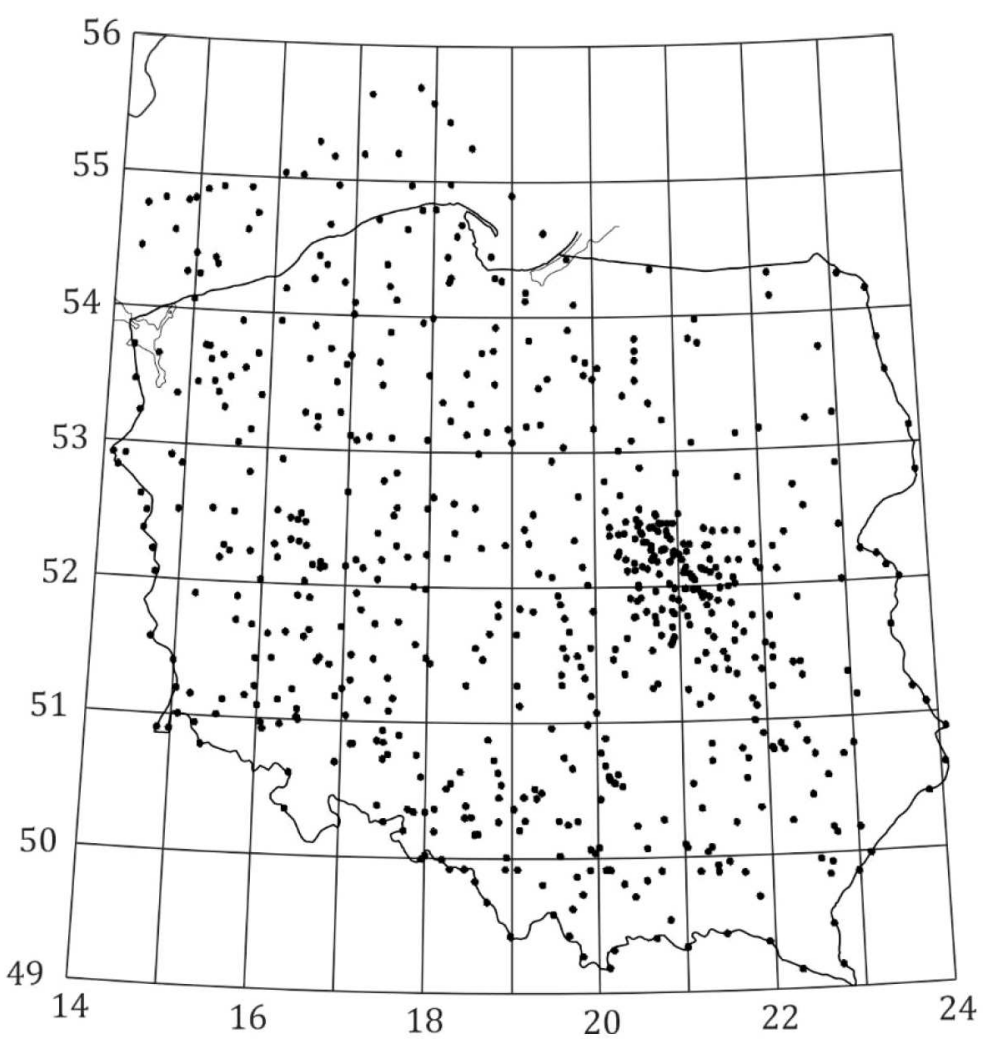

Rys. 2. Rozmieszczenie na terenie Polski wszystkich znaczących punktów nawigacyjnych (WP) [15] 
Do końca 2019 r. 55 ACC w Europie całkowicie lub częściowo wdrożyło operacje w przestrzeni FRA. Coraz częściej ośrodki kontroli ACC wdrażają operacje transgraniczne zgodnie z zasadami FRA, tak bardzo jak to jest możliwe. Pełne wdrożenie FRA w całej Europie spodziewane jest do $2023 / 2024 \mathrm{r}$.

\section{Systemy komputerowego planowania lotów}

Odpowiednie zaplanowanie lotu jest zadaniem trudnym i wymagającym ze względu na złożoność przestrzeni powietrznej oraz konieczność uwzględnienia uwarunkowań i ograniczeń zewnętrznych, a także potrzebę optymalizacji trasy lotu. Pełne wykorzystanie możliwości nowego sposobu planowania lotów (FRA) będzie możliwe tylko przy wykorzystaniu metod optymalizacji, pozwalających na zaplanowanie trasy $4 \mathrm{D}$ z uwzględnieniem czynników zewnętrznych oraz ograniczeń systemu ATM dla optymalnych wartości kryteriów [4], [5], [7], [10].

System planujący lot musi dysponować odpowiednimi modelami obliczeniowymi: samolotu, przestrzeni powietrznej, trasy lotu oraz ruchu lotniczego. Dodatkowo musi mieć dostęp do aktualnych warunków pogodowych oraz informacji na temat bieżącego i planowanego ruchu lotniczego oraz stanu przestrzeni powietrznej. Wszystkie te elementy będą wykorzystywane przez odpowiedni algorytm obliczeniowy, który będzie wyznaczał optymalny profil lotu dla zadanego kryterium (koszt, zużycie paliwa itp.), przy uwzględnieniu aktualnych warunków wykonania lotu i obowiązujących ograniczeniach (restrykcje, strefy zakazane itd.) [7], [12], [13].

Obliczeniowy model samolotu jest niezbędny do wyznaczenia charakterystyk zużycia paliwa dla zadanych parametrów technicznych samolotu i warunków operacyjnych wykonywania lotu. W zależności od fazy lotu obliczeniowy model samolotu pozwala na wyznaczenie najważniejszych charakterystyk osiągowych, które następnie mogą być wykorzystane do oszacowania kosztów lub innych wskaźników pełniących rolę kryteriów. Dane wejściowe to między innymi parametry definiujące warunki lotu, np. wysokość, prędkość, chwilowa masa samolotu, warunki atmosferyczne oraz pogodowe, np. prędkość i kierunek wiatru. Jednym z najważniejszych czynników wpływających na ilość zużytego paliwa, czas i koszt przelotu samolotu jest pogoda. Algorytm obliczeniowy wyznaczający mase paliwa, czas lotu i ostatecznie jego koszt na etapie planowania lotu powinien wykorzystywać najlepsze prognozy pogody, do jakich jest dostęp. Pozwoli to na minimalizację błędu oszacowania parametrów oraz optymalizację trasy lotu uwzględniającą najbardziej korzystne warunki jego wykonania. Oprócz typowych parametrów, takich jak ciśnienie i gęstość powietrza, szczególną uwagę należy przywiązać do prawidłowego wyznaczenia temperatury oraz prędkości i kierunku wiatru. Od temperatury zależy prędkość dźwięku, która pozwala na prawidłowe wyznaczenie liczby Macha dla samolotu lecącego z daną prędkością rzeczywistą. Prędkość i kierunek wiatru ma zaś wpływ na prędkość samolotu względem ziemi.

\section{1. $\quad$ Model przestrzeni powietrznej}

Jako model przestrzeni powietrznej wybrany został graf (rys. 3) o strukturze odwzorowującej najważniejsze cechy, ograniczenia i restrykcje obowiązujące w danym momencie, składający się z węzłów i krawędzie, którym będą mogły być przypisywane odpowiednie wagi [1], [7], [11]. Trajektoria samolotu w przyjętym modelu przestrzeni powietrznej reprezentowana będzie przez zbiór wierzchołków grafu oraz krawędzi, wzdłuż których poruszał się będzie samolot. Wierzchołki grafu opisane będą współrzędnymi geograficznymi, zaś położenie samolotu określane będzie wysokością i czasem w punktach węzłowych grafu.

Trajektoria w grafie opisana będzie więc w postaci łamanej opartej na wielu węzłach i łączących je krawędziach. Węzły te jednak nie będą traktowane jako punkty nawigacyjne (WayPoint - WP), lecz będa tylko definiowały wstępny kształt trasy lotu. Trasa ta zostanie w kolejnych etapach poddana obróbce mającej na celu „wyprostowanie” trasy początkowej z warunkiem 
minimalizacji punktów zwrotnych, bez istotnego pogarszania jakości wyniku. Dopiero wersja końcowa trasy („wyprostowana”) będzie wykorzystywana do złożenia planu lotu.

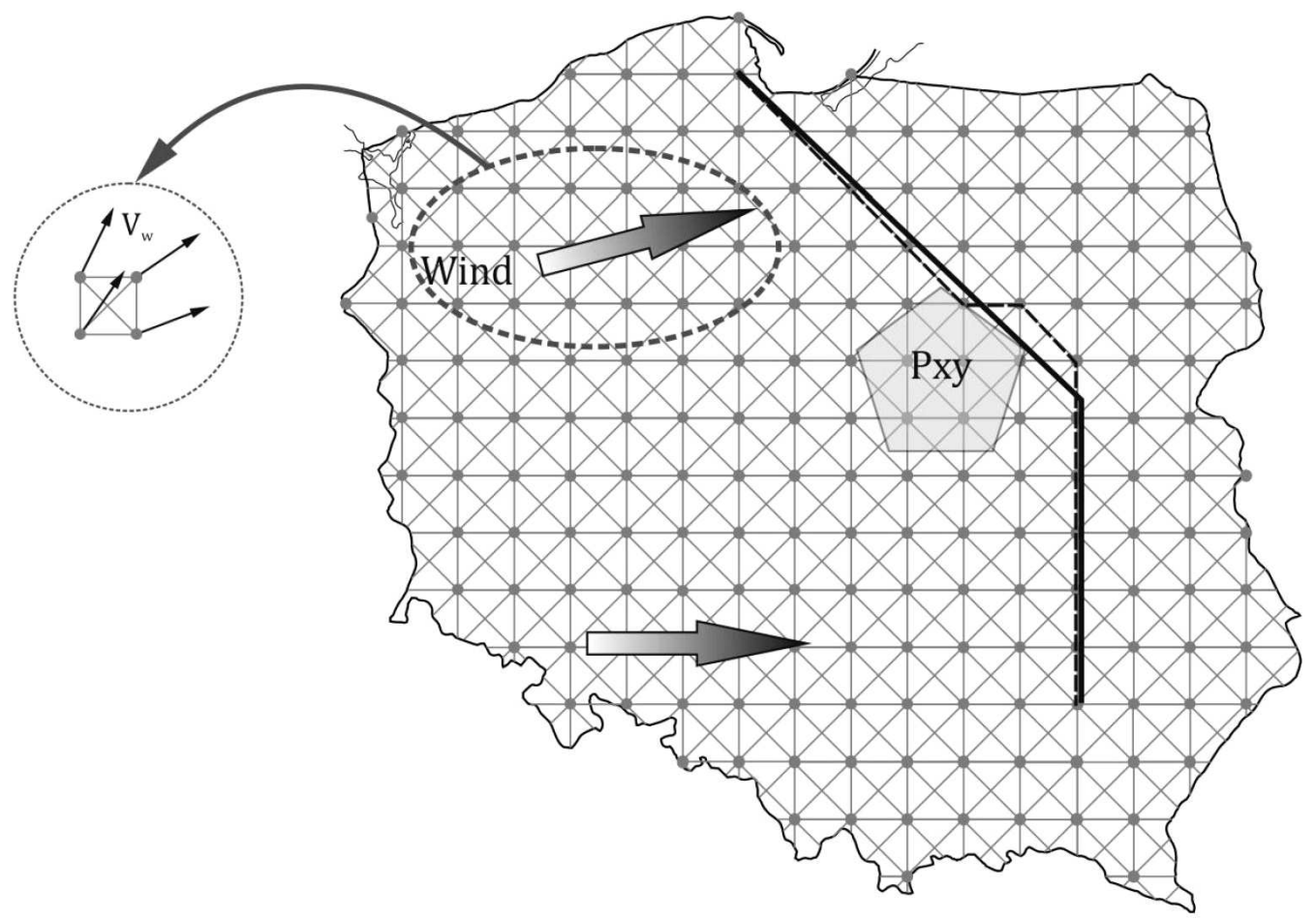

Rys. 3. Model przestrzeni powietrznej z wyznaczoną najkrótszą drogą (linia przerywana) oraz wyznaczoną na jej podstawie trasą lotu (linia ciągła)

Problem, który może zostać opisany modelem w postaci grafu, definiowanego węzłami (wierzchołkami), krawędziami i wagami przypisanymi do krawędzi może być rozwiązywany klasycznymi metodami poszukiwania ścieżki ekstremalnej. Może tu być wykorzystany algorytm Dijkstry, opracowany przez holenderskiego informatyka Edsgera Dijkstrę [1], [11], służący do znajdowania najkrótszej ścieżki z pojedynczego źródła w grafie o nieujemnych wagach krawędzi. Ponieważ wagi przypisane krawędziom będą oznaczały odległość pomiędzy węzłami, koszt pokonania tej odległości lub inne podobne wielkości, to wagi zawsze będę spełniały warunek nieujemności.

Przykład trasy wyznaczonej w grafowym modelu przestrzeni powietrznej pokazany został na rysunku 3 (linia przerywana). Trasa ta następnie została poddana dalszej obróbce, mającej na celu otrzymanie trasy możliwej do realizacji w warunkach operacyjnych (linia ciągła). W obliczeniach pokazano również przykładowe położenia strefy zakazanej (rys. 3, Pxy), którą wyznaczana trasa musi ominąć. W rozważanym przykładzie trasa wyznaczona została przy założeniu minimalnej odległości powietrznej pokonywanej przez samolot. Rozwiązanie bardzo mocno zależy od warunków pogodowych i dla innej prędkości i innego kierunku wiatru otrzymuje się różne trasy. Dokładność obliczeń zależy również od rozłożenia punktów węzłowych grafu modelującego przestrzeń powietrzną i dobór tych odległości powinien zostać osobno rozważony.

\section{Optymalizacja trasy}

Opracowany algorytm optymalizacji trasy wykorzystany został do znalezienia optymalnej trasy lotu samolotu w Polskiej przestrzeni powietrznej FIR Warszawa, dla wybranych dwóch lotnisk: Rzeszów-Szczecin (rys. 4). Do obliczeń przyjęto najwyższy poziom złożoności przestrzeni powietrznej z aktywnością wszystkich stref wojskowych. 


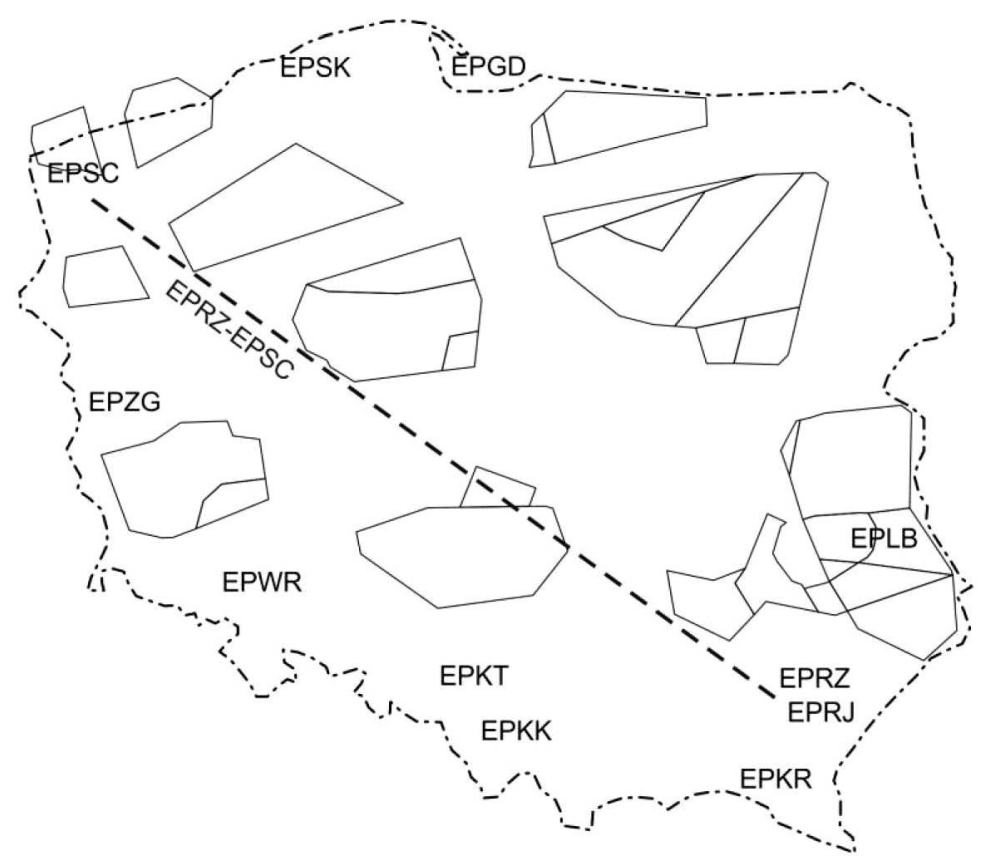

Rys. 4. Kierunek trasy Rzeszów-Szczecin

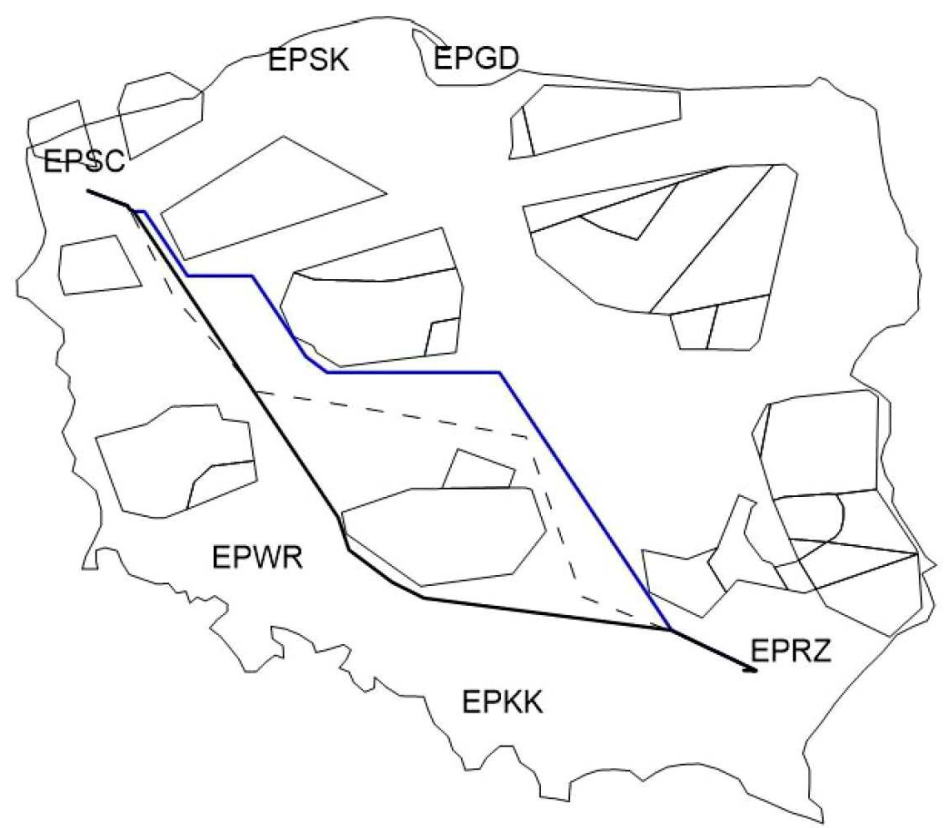

Rys. 5. Optymalne trasy wyznaczone przez algorytm planowania tras (linia przerywana - AWY, linia ciągła południowa - Full FRA)

Opracowany algorytm, bazujący na metodzie Dijkstry, przyjętym modelu przestrzeni powietrznej (rys. 3) oraz wykorzysujący algorytm Ramera-Douglasa-Peuckera do minimalizacji liczby punktów trasy (WP), wykorzystany został do wyznaczenia trasy lotu z lotniska EPRZ do lotniska EPSC dla trzech sposobów planowania trasy:

- według dróg lotniczych (AWY),

- w przestrzeni FRA, uwzględniając tylko oficjalne punkty zwrotne (Limited FRA),

- w przestrzeni Full FRA, z możliwością definiowania własnych punktów trasy.

Wyniki otrzymane z wykorzystaniem algorytmu przedstawione zostały na rysunku 5. 
Obliczenia wykonano dla samolotu Piper Seneca V wykonującego lot w warunkach bezwietrznych. Pokonane odległości oraz czasy lotu dla trzech wykorzystanych metod planowania trasy przedstawiono w tabeli 1.

Tabela 1. Pokonane odległości i czasy lotu dla tras zaplanowanych według trzech metod

\begin{tabular}{|l|c|c|c|}
\hline \multicolumn{4}{|c|}{ Trasa lotu: EPRZ - EPSC } \\
\hline Wielkość & $\begin{array}{c}\text { Scenariusz } \\
\text { odniesienia (AWY) }\end{array}$ & Full FRA & Limited FRA \\
\hline \hline Odległość $[\mathrm{km}]$ & 704 & 696 & 703 \\
\hline Czas [min] & 182 & 180 & 181 \\
\hline
\end{tabular}

Weryfikacja została przeprowadzona dla tradycyjnego sposobu planowania trasy (AWY) wzdłuż dróg lotniczych. Trasa zaplanowana ręcznie pomiędzy punktami TOC (Top of Climb) a TOD (Top of Descent) przebiegała wzdłuż tych samych punktów, które wybrał zautomatyzowany algorytm planowania tras.

\section{Ocena wykonalności trasy}

Ocena wykonalności trasy, stanowiąca walidację algorytmu planowania trasy, przeprowadzona została z wykorzystaniem symulatora lotu SIMVISION HIBRID FNTP II MCC, będącego własnością Politechniki Rzeszowskiej. Symulator pozwala na wykonywanie lotów symulowanych w czasie rzeczywistym na 4 typach samolotów. Do prac walidacyjnych wybrano samolot dwusilnikowy o napędzie tłokowym o charakterystykach samolotu klasy Piper Seneca V. Schemat symulatora przedstawiono na rysunku 6.

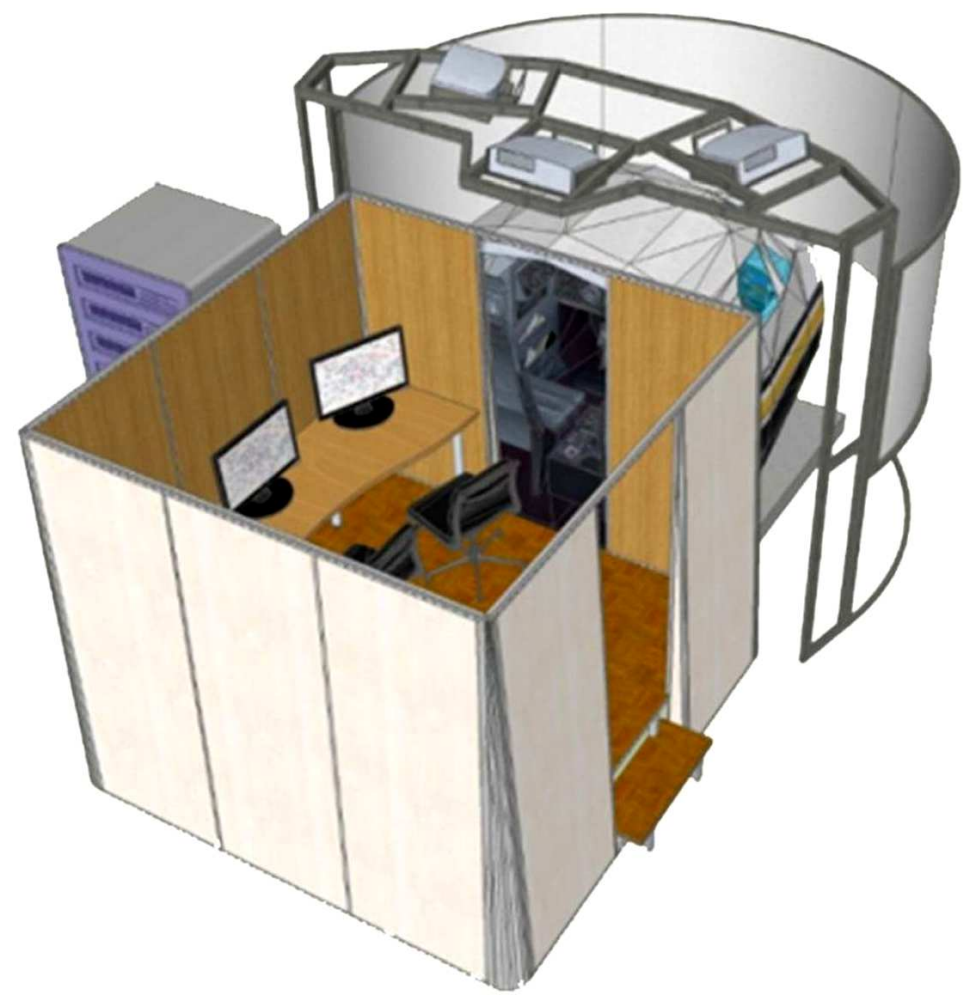

Rys. 6. Schemat symulatora SIMVISION HIBRID FNTP II MCC stanowiącego platformę walidacyjną 
Otrzymaną na podstawie obliczeń trasę lotu wprowadzono do komputera pokładowego symulatora, a następnie załoga składająca się z pilotów zawodowych wykonała lot z wykorzystanie autopilota. Otrzymane wyniki, pokonana odległość oraz czas lotu zawarto w tabeli 2.

Tabela 2. Pokonane odległości i czasy lotu symulowanego

\begin{tabular}{|l|c|c|c|}
\hline \multicolumn{4}{|c|}{ Trasa lotu: EPRZ - EPSC } \\
\hline Wielkość & $\begin{array}{c}\text { Scenariusz } \\
\text { odniesienia (AWY) }\end{array}$ & Full FRA & Limited FRA \\
\hline \hline Odległość $[\mathrm{km}]$ & 705,65 & 696,96 & 702,99 \\
\hline Czas [min] & 184,8 & 179,75 & 181,26 \\
\hline
\end{tabular}

Otrzymane wyniki (tabela 2) wykazują bardzo wysoką zgodność z wielkościami wyliczonymi przez algorytm planowania tras (tabela 1), co wskazuje na wysoką wierność odwzorowania trasy zaplanowanej $\mathrm{w}$ trakcie lotu symulowanego. Stanowi to również dowód na to, że trasa zaplanowana przez algorytm jest wykonalna w warunkach zbliżonych do rzeczywistego lotu.

\section{Uwagi końcowe}

Proces planowania lotu, w szczególności dla nowej koncepcji swobodnie planowanych tras przelotu (FRA), może zostać ulepszony poprzez wykorzystanie zautomatyzowanego systemu wyznaczającego optymalną trasę lotu na podstawie wszelkiej dostępnej informacji. Opracowanie systemu, który w sposób automatyczny zaplanuje lot, wymaga przyjęcia odpowiednich założeń oraz opracowania niezbędnych modeli oraz algorytmów obliczeniowych, takich jak [5], [7], [8], [11]:

- model samolotu, model przestrzeni powietrznej, model trasy lotu, model ruchu lotniczego, model środowiska zewnętrznego, itp.,

- algorytm optymalizujący automatycznie wygenerowaną trase przelotu dla zadanej funkcji kryterialnej.

Opracowany algorytm planowania tras w oparciu o metodę Dijkstry poszukiwania optymalnej ścieżki w grafie modelującym przestrzeń powietrzną, uzupełniony o metodą minimalizacji punktów węzłowych trasę wykorzystującą algorytm Ramera-Douglasa-Peuckera, pozwala uzyskać trasę lotu, która jest wykonalna z bardzo wysoką wiernością odtworzenia w warunkach lotu rzeczywistego.

\section{Bibliografia}

1. Deo N., Teoria grafów i jej zastosowania w technice i informatyce, Biblioteka Naukowa Inżyniera, PWN, Warszawa, 1980

2. EUROCONTROL, European Aviation in 2040. Challenges of Growth. Annex1. Flight Forecast to 2040, European Organisation for the Safety of Air Navigation, Brussels, 2018

3. EUROCONTROL, Free Route Airspace Developments. For a Route-Free European Network, European Organisation for the Safety of Air Navigation, 2016

4. Kopecki G., Pęczkowski M., Rogalski T., Przykładowy algorytm wyznaczania trasy przelotu w Przestrzeni Lotów Swobodnych, Autobusy, 6, 2017

5. Krzyżanowski M., Conflict free and efficient flight routes planning in Free Route Airspace, Prace Naukowe Politechniki Warszawskiej, Transport, 95, Warszawa, 2013 
6. Malarski M., Inżynieria ruchu lotniczego, Oficyna Wydawnicza Politechniki Warszawskiej, Warszawa, 2006

7. Majka A., Pawluczy J., Rogalski T. Zautomatyzowany algorytm planowania lotu samolotu w przestrzeni FRA, [W:] Mechanika w Lotnictwie, ML-XVIII 2018, K. Sibilski (Red.), ZG PTMTS, Warszawa, 2018

8. Murrieta-Mendoza A., Mugnier P., Botez R.M., Vertical and horizontal hlight reference trajectory optimization for a commercial aircraft, AIAA Guidance, Navigation, and Control Conference, AIAA SciTech Forum, AIAA 2017-1241, 2017

9. Skorupski J., Wspólczesne problemy inżynierii ruchu lotniczego. Modele i metody, Praca zbiorowa, Oficyna Wydawnicza Politechniki Warszawskiej, Warszawa, 2014

10. Tomczyk A., Rogalski T., Bakunowicz J., Koncepcja przygotowania i koordynacji planów lotów IFR w Obszarze Lotów Swobodnych, Autobusy, 6, 707-713, 2016

11. WŁoch A., WŁoch I., Marematyka dyskretna, Oficyna Wydawnicza PRz, Rzeszów, 2008

12. Wytyczne Nr 3 Prezesa Urzędu Lotnictwa Cywilnego z dnia 16 kwietnia 2014 r. w sprawie ogłoszenia wymagań ustanowionych przez Organizację Międzynarodowego Lotnictwa Cywilnego (ICAO) Doc. 4444, „Dziennik Urzędowy Urzędu Lotnictwa Cywilnego” Warszawa, dnia 16 kwietnia 2014 r.

Witryny internetowe:

13. http://www.ulc.gov.pl/pl/prawo/projekty/krajowe/w-konsultacjach/3607-art-33-ust-2-i-4, Projekt rozporządzenia Ministra Infrastruktury i Rozwoju zmieniającego rozporządzenie w sprawie wyłączenia zastosowania niektórych przepisów ustawy - Prawo lotnicze do niektórych rodzajów statków powietrznych oraz określenia warunków i wymagań dotyczących używania tych statków, Urząd Lotnictwa Cywilnego [dostęp: październik 2020]

14. https://www.eurocontrol.int, EUROCONTROL [dostęp: październik 2020]

15. http://www.pansa.pl/, Polska Agencja Żeglugi Powietrznej, PAŻP [dostęp: październik 2020]

16. https://www.sesarju.eu, SESAR JU [dostęp: październik 2020]

\section{Verification and validation of the new route planning algorithm in the FRA}

Europe is facing an airspace capacity crisis as the number of flights is forecasted to increase by up to $50 \%$ in the next 10 to 20 years. The low efficiency caused by fragmentation of European airspace creates high additional costs every year, mainly borne by airlines and passengers. Due to the applicable flight planning rules, flight plans are rarely compatible with their operational execution. The effect of this is low predictability of air traffic, affecting a large workload on air traffic controllers during resolution of conflict situations and long delays in air traffic. The inability to effectively optimize the flight routes at the flight planning stage means that European flight routes are longer than optimal ones, which in turn means higher fuel consumption, increased emissions and higher costs for users. The paper presents a new algorithm for planning routes in the FRA, which allows taking into account the complexity of the airspace and its limitations. The developed algorithm can be used in automated flight planning systems available for non-commercial users (General Aviation) or smaller aviation companies (Business Aviation, Remotely Piloted Aircraft Systems). The algorithm results were verified by comparing the obtained routes with those planned manually by professional pilots with extensive aviation experience. The validation showing the feasibility of the planned routes was carried out using the FNPT II flight simulator during simulated flights in real time. 